\title{
THE DECIMAL SYSTEM IN BRITAIN
}

$\mathrm{D}^{\mathrm{c}}$ URING the past two years, committees appointed by the British Association and by the Association of British Chambers of Commerce have been examining the merits or demerits of the adoption by the United Kingdom of the decimal system of coinage and/or the metric system of weights and measures. A joint report, to which Sir Alexander Fleck contributes a foreword, has now been issued*, based on inquiries made of some 2,000 organizations, including trade associations, chambers of commerce, individual companies, learned societies and professional institutions. The report is in four parts, examining first the question of decimal coinage and then that of the metric system. In each of theso parts, earlier inquiries in the United Kingdom are reviewed, and then the implications and morits of a change are considered, the cost factors and, for the metric systom, the international aspects. In the third part, the improvement of the Imperial system is discussed, and in the fourth, the educational aspects such as the problems for schools and adult oducation.

On all the available evidence, the Committees consider that there is a strong case for the adoption of a decimal system of coinage, and, as Sir Alexander Fleck points out, this is a policy that lies wholly within our own control to dotermine: no international complications are involved. The Committees found little dissatisfaction expressed with the present system of coinage in industry and commerce, but wide approval of the concept of decimal coinage. There was some disagreomont as to the preferred methed of decimalization, but an overwhelming wish to retain the pound sterling es the major unit. If this is accepted, the pound/mil, or pound/cont, with the cent suitably subdivided, systems appoar to be the most suitable, and these systems are also the most popular. Decimalization of the coinage would be heipful by simplifying money calculations, with particular advantages in the fields of business machines and education. It is primarily a domestic question; but any system which involved abandoning the pound as the major unit might lower the status of British currency. Decimalization of the coinage would give only slight advantage in intornational trade, and while, so far as the Committees could ascertain, the transitional costs of decimalization would be heavy, they would not be unduly large in relation to the resources of the country and the long-term benefits that would accrue. The question should be considered on its own merits independently of the system of weights and measures, but decimalization of the coinage should precede any future plan for the adoption of the metric system.

Since the evidence before the Committees was received mainly from industry and commerce, it may not accuratoly roflect public opinion either on tho principle or the method of decimalization. General approval and understanding on the part of the public would be essential, and the report is intended in the first place to stimulate such informod discussion. The Committees believe, however, that the time has

- Decimal Coinage and the Metric System : Shonld Britain Change? (A joint report of Committees appointed by the British Association for the Advancement of Science and the Association of British Chambers of Commerce.) Pp. $x \mathbf{i}+107$. (London: Butterworths Sclentific Publications, 1960.) $7 s, 6 d$. come for a decision to be made in principle on this question, and this decision can only be made by the Government. They recommend that the Government should aim at taking an early decision in principle for or against the adoption of a decimal coinage; but that before taking such a decision further inquiries should be made, including a sounding of public opinion and efforts to inform the public on the issues involved. The Committees find that a minimum of three years notice would be required to make essential preparations for the adoption of decimal coinage, and this poriod of notice should provide ample time to familiarize the public with the new system.

Even more emphatically, so far as weights and moasures are concerned, gradualnoss is the keynote of the Committees' recommendations, although they do not recommend compulsory adoption of the metric system by the United Kingdom at the present time. The metric system is already legal for most purposes in the United Kingdom, and it would be possible for adoption to proceed piecemeal on a voluntary basis. For the purpose of the inquiry the view was taken that 'adoption' of the metric system by the United Kingdom meant a general adoption over a limited term of years, at the ond of which the metric systern would bocome the generally accopted system, and the Imperial system would fall into disuse.

The Committees found that little use is made to-day of the metric system in the United Kingdom except for scientific and laboratory purposes and in a few specialist fields, particularly the pharmaceutical and optical industries and scientific instruments. There is little sign here of any significant trend towards increased use, except in manufacture for, or packing for, export to motric countries, and there is no strong feeling in industry or commerce that Britain is being adversely affected either internally or in exports to metric countries by the retention of the Ixrperial system. Conversely, the same appears to bo broadly true of manufacturers in metric countries in their efforts to soll in non-metric countries. The Committees agreed that the question of units of woights and measures is of minor importance compared with many other factors influencing tho flow of international trade. There is a majority opinion that the United Kingdom should keep in line with the Commonwealth and the United States.

Although there is general agreement on the desirability of increasing standardization, there is some divergence of opinion as to how this should be achieved. At present, there still appears to be an inadequate body of agreed international standards as between the various metric countries, and certain sections of the engineering industry hold that the United Kingdom would be ill-advised to abandon such standardization as already exists in the nonmetric world. Moreover, non-metric usage exists in a few industries on a world-wide basis, for oxample, in the oil industry, shipping, and to a high degree in aircraft manufacture and air navigation.

Generally, it is clear that transitional costs would be vory hosvy in some spheres, particularly engineering, but the financial benefits are difficult to assess. Should the United Kingdom decido to adopt the metric system, at least ten and sometimes 20-30 
vears would be required for the complete change-over, and the longer the period of change-over the lower the total transitional costs. Educational benefits are real, but are not easily measurable in terms of money. The Committees stress the existence of a general feeling that the metric system will in course of time become more widely used in the rest of the world and the United Kingdom. They recommend, therefore, a regular two-yearly review by the Board of Trade in consultation with industry and commerce, and in conjunction with corresponding bodies in the Commonwealth and the United States, and paying particular attention to trends in Japan and India and the under-developed countries of Asia and Africa. These reviews should indicate what stimulus might be given to more rapid change-over to the metric system in the United Kingdom and in what soctions of industry and commerce metric usage could be introduced with most benefits and the least transitional dislocations. It is suggested that there may be a case for the British Standards Institution pub. lishing further metric standards to facilitate manufacture in metric dimensions for export.

The Committees agree that there is real advantage to be gained now by increased rationalization of the Imperial system, and they recommend that this should be further studied. This is a specialist matter for each industry ; but they suggest that all Govern- ment departments and nationalized industries could examine the practicability of eliminating intermediate units of weight between the ton and the pound avoirdupois ; alternatively, use of the cental $(100 \mathrm{lb}$.) should be encouraged in place of the hundredweight, and there should be a short ton of $2,000 \mathrm{lb}$. in place of the long ton of $2,240 \mathrm{lb}$. They also recommend that the apothecaries' troy and pennyweight systems be removed from school curricula, and that the rod, pole or perch of $5 \frac{1}{2}$ yards and the corresponding square measure of 301 square yards be officially abolished, and that use of the decimalized inch in place of fractions be increased. Finally, under educational aspects, they recommend that even if no action be taken on decimal coinage or the metric system, much greater emphasis should be placed forthwith on the teaching and use of decimals and the metric system in the educational curriculum of Britain from the earliest stages. This would not only promote 'decimal thinking' at an earlier age than at present, but would also be of value to entrants into industry and commerce, where the practical use of decimals is increasing.

Appendixes to the report present extracts from evidence received on decimal coinage and the metric system, and group the countries of the world according to their adoption or not of the metric system.

\section{SELECTION OF EXECUTIVES}

$\mathrm{D}$ URING the years immediately after the Second World War, it was the fashion for amateur and professional psychologists to see 'significance' in a great variety of phenomena, from handwriting to the choice of a wife, from remarks made during a group discussion to readiness to become angry at an interview, from imagined shapes seen in an ink-blot to the design created with a set of mosaics. That any one of these actions can be significant of itself was an assumption which has invalidated much of the psychology of personality testing during the past ten years, and such is the subject of a recent article in the European Productivity Agency Bulletin (No. 34 ; February 1960).

The recent trend has been a healthy one. Amateur psychologists are not so respected in their assessment of significant revelations. Professional psychologists have considerably limited their claims and disciplined their methods, thereby increasing their effectiveness. But much indisciplined personality testing still goes on. Recently, a works manager was appointed solely on the judgment of the managing director's wife's interpretation of the applicant's handwritten signature to a typewritten letter. A brilliant technologist was rejected in favour of a less-qualified man because he did not take a lead in a discussion with other candidates during a specially organized hotel dinner. A psychiatrist employed by a large organization in London interviews candidates for the higher staff grades and deliberately sets out to anger them, judging from the time it takes them to lose their tempers whether or not they have initiative.

Warren Lamb suggests that it is an imposition to subject a candidate to having his individual actions judged as to their significance and what they reveal without being able to defend himself. The existence of significance testing is due to two fallacies under- lying the most scrupulous application of pure psychological research within industry and commerce: (a) that a test situation can be so devised that the candidate's response will be identical with what it would be on other occasions ; $(b)$ that a quality once measured (for example, dominance, perseverance) will apply in all conditions.

Validating procedures have so narrowed down the aims under $(a)$ that the results of properly validated present-day performance tests are so prescribed as to make only a minor contribution to industrial selection and appraisal. The simplest of casual observation will dispose of $(b)$. One would not have to search far to find the dominant business man and the submissive husband. A recent survey of top-ranking business executives in England revealed that the greatest common characteristic was extreme shyness.

Is it possible to have any form of personality testing which does not depend upon attributing significance to any one action or response? One method has been devised based on an analysis of constant elements in a person's movements.

No two people move in exactly the same way; in habitual adjustments of posture, gestures, handling of objects, a way of walking and so on, there are distinct individual differences. It has been found that everyone has certain movement co-ordinations which are constant to all his activities. That is to say, there are certain elements in the total movement which remain constant whatever the person's behaviour or emotion. For example, these elements will remain constant during an occasion when the person is sitting relaxed enjoying a casual conversation, and on another occasion when he is giving a demonstrative, angry, fiery political speech. Sets of observations taken on each occasion, and analysed separately, produce an identical result. 